\title{
Lumbar Intradural Extramedullary Bronchiogenic Cyst
}

\author{
S. Chongyi ${ }^{\mathrm{a}} \quad$ Y. Meng $^{\mathrm{a}} \quad$ Y. Dejun ${ }^{\mathrm{a}} \quad$ L. Yingjie $^{\mathrm{b}} \quad$ L. Qingpeng $^{\mathrm{a}}$ \\ Departments of a Orthopaedics and ${ }^{\mathrm{b}}$ Pathology, 2nd Hospital of Harbin Medical University, Harbin, China
}

\section{Key Words}

Bronchiogenic cyst, surgery • Intraspinal • Pathology

\section{Abstract}

The pathological findings of an intradural and extramedullary cyst at the $\mathrm{L} 1$ level of the spinal canal are described in a 28-year-old male who presented with chronic lumbago and progressive weakness and numbness in both lower limbs. Histopathological examination revealed the diagnosis of bronchiogenic cyst. Bronchiogenic cysts in the spinal canal are uncommon, and cysts at the L1 level are extremely rare. Their pathogenesis is still poorly understood. They are thought to be a malformation arising from a split notochordal syndrome. We conclude that intradural extramedullary bronchiogenic cysts may appear also at lumbar levels. Surgical resection can be achieved with good outcome.

Copyright $\odot 2008$ S. Karger AG, Basel

\section{Case Report}

A 28-year-old male presented with chronic lumbago for a year and progressive weakness and numbness in both lower limbs for 2 weeks. There were no urinary or defecation problems.

The neurological examination showed hypoesthesia and $4 / 5$ muscle strength of his right lower extremity. The bilateral tendon reflexes of the lower extremity were overactive. Babinski could not be elicited on either side. Magnetic resonance imaging of the lumbar vertebrae revealed an intradural extramedullar mass located at the L1 level (fig. 1).

\section{KARGER}

Fax +41613061234

E-Mail karger@karger.ch

www.karger.com (c) 2008 S. Karger AG, Basel

0014-312X/08/0401-0026\$24.50/0

Accessible online at:

www.karger.com/esr

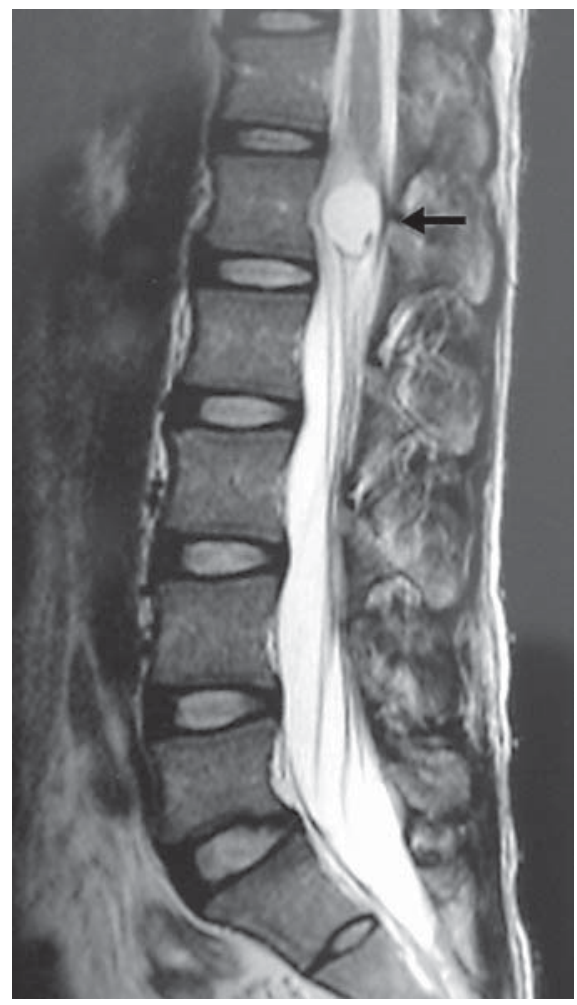

Fig. 1. The arrow shows an intradural extramedullary cyst at the L1 level.

\footnotetext{
Liu Qingpeng

Department of Orthopaedics

2nd Hospital of Harbin Medical University, No. 246 XuFu Road

Harbin, Heilongjiang Province 150086 (China)
}

Tel. +861393632 1195, E-Mail spine1972@yahoo.com 
A laminectomy of L1 and partial T12, L2 was performed. The lesion was well exposed by a longitudinal opening of the dura along its midline. It was a fluid-containing, $2.0 \times 1.7 \times 1.5 \mathrm{~cm}$ cystic lesion, which was adherent to the dorsal conus medullaris and the cauda equina. Yellow viscous liquid in the cyst was sucked out. The cystic wall was partially resected and was sent for pathological examination. Total resection was impossible due to the inevitable injury to the conus and cauda equina. No postoperative complications occurred. The preoperative symptoms disappeared completely.

\section{Pathological Findings}

The specimen was a unilocular, thin-walled cyst, the inner surface of which was lined with pseudostratified ciliated columnar epithelium. Within the subepithelial stroma mucous and serous glands were present, which were found regularly in the normal tracheobronchial tract (fig. 2-4).

\section{Discussion}

The intraspinal cysts have various types. The here described cyst has the histopathological appearance with the ciliated lining epithelium and the wall containing mucous and serous glands. It was referred to as bronchogenic cyst [1], similar to that of the mediastinum $[2,3]$. Ho and Tiel [4] further confirmed the bronchial characteristic of such a cyst by ultrastructural research. In their study 6 cell types were identified, namely ciliated cells, nonciliated cells, goblet cells, basal cells, Kulchisky's cells and undifferentiated cells. The cell types and their topographic distribution are similar to that of the human bronchial epithelium. They also considered that the epithelium of the bronchiogenic cyst is consistent with the upper respiratory tract, particularly the tracheobronchial portion, because of the absence of Clara cells, which in humans are found only in the bronchioles.

Bronchiogenic cysts are developmental abnormalities of the central nervous system [5]. The definite developmental mechanisms of such cysts are still unknown. However, they are generally believed to derive from an

Fig. 2-4. The serous gland (arrow 2) and mucous gland (arrow 1) are well shown. Pseudostratified ciliated columnar epithelium is shown by arrow 3 . Fig. $\mathbf{2} \times 100$. Fig. 3, $\mathbf{4} \times 400$.
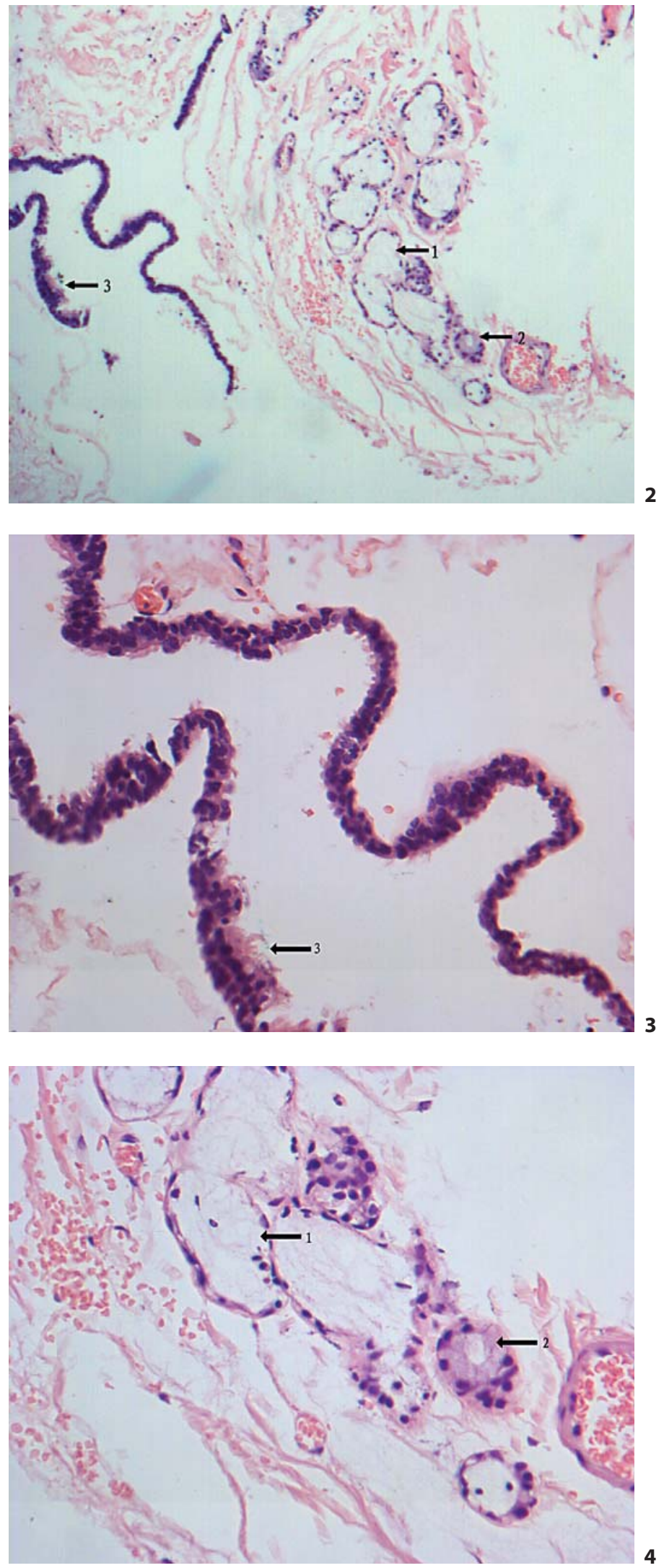

4 
anomalous embryological connection between the primitive foregut and the developing neural tube, probably in association with splitting or reduplication of the intervening notochord [6].

Bronchiogenic cysts have been found attached to the sternum, skin, stomach, pericardium and mediastinum, whereas intraspinal cases are extremely uncommon. Baumann et al. [7] reported an intraspinal bronchiogenic cyst and conducted a literature review in 2005. In all the cases in his review, the lesion localized at a cervical or upper thoracic level except 1 at the T12-L1 level reported by himself. The here presented cyst at the L1 level was exceedingly rare.

Bronchiogenic cysts usually grow slowly due to the tight junctions between the epithelial cells which may limit the amount of expansion [8]. There are no instances of canceration developing within these intraspinal bronchiogenic cysts, but malignancies of the cyst in the mediastinum, including adenocarcinoma and rhabdomyosarcoma, have been reported $[9,10]$. The most effective management to intraspinal bronchiogenic cysts was surgical resection. The patient's symptoms usually relieve, as we reported, after the cyst is removed. Total resection of the cyst is the goal of surgery. Nevertheless, this has not been achieved in most of the cases. Only $36 \%$ of the cysts reported in the literature have been removed totally [11], either because of the ventral location related to cord or because of the adherence of a part of the cyst to the medullary substance.

\section{References}

1 Yamashita J, Maloney AF, Harris P: Intradural spinal bronchiogenic cyst: case report. J Neurosurg 1973;39:240-245.

-2 Dorsey JF, Tabrisky J: Intraspinal and mediastinal foregut cyst compressing the spinal cord: report of a case. J Neurosurg 1966;24: 562-567.

- 3 Eraklis AJ, Griscom NT, McGovern JB: Bronchogenic cysts of the mediastinum in infancy. N Engl J Med 1969;281:1150-1155.

-4 Ho KL, Tiel R: Intraspinal bronchogenic cyst: ultrastructural study of the lining epithelium. Acta Neuropathol (Berl) 1989;78: 513-520.
5 Ironside JW, Moss TH, Louis DN, et al: Diagnostic Pathology of Nervous System Tumors. New York, Churchill Livingstone 2002, pp 528-532.

6 Kulkarni V, Daniel RT, Haran RP: Extradural endodermal cyst of posterior fossa: case report, review of the literature, and embryogenesis. Neurosurgery 2000;47:764-767.

7 Baumann CR, Konu D, Glatzel M, Siegel AM: Thoracolumbar intradural extramedullary bronchiogenic cyst. Acta Neurochir (Wien) 2005;147:317-319; discussion 319.

8 Hirano A, Ghatak NR, Wisoff HS, Zimmerman HM: An epithelial cyst of the spinal cord: an electron microscopic study. Acta Neuropathol (Berl) 1971;18:214-223.
9 Gotti G, Haid MM, Volteranni L, Sforza V: Unusual malignancy in the wall of a mediastinal cyst. J Thorac Cardiovasc Surg 1993; 106:1233-1234.

10 Olsen JB, Clemmensen O, Andersen K: Adenocarcinoma arising in a foregut cyst of the mediastinum. Ann Thorac Surg 1991;51: 497-499.

11 Paleologos TS, Thom M, Thomas DG: Spinal neurenteric cysts without associated malformations: are they the same as those presenting in spinal dysraphism? Br J Neurosurg 2000;14:185-194. 